are sufficiently interested in, or informed of, this particular public service, and hence whether they are qualified to come to any conclusion at all about such 'needs'. One more statement from the article under consideration is worth quoting for the light it throws upon a not uncommon official attitude towards museums : "Museums have been the Cinderellas of the services for too long a time". It is evident, therefore, that many of these institutions are at present in a state of suppression, and that the cause may be ill-informed, ungenerous, or timid rule. It is evident, also, that various authorities, whether they are responsible for the conduct of a museum service or not, have yet to be convinced of the value of the museum in the fields of education and research, and in the intelligent and constructive use of leisure.

\section{HISTORICAL LIBRARY OF YALE UNIVERSITY SCHOOL OF MEDICINE}

$\mathrm{T}$ $\mathrm{HE}$ difficulties of scientific libraries, the meagre funds sometimes allocated to them and the devoted labours of those who work obscurely in them for the benefit of science are often not adequately appreciated by those who would be the first to maintain that libraries are essential tools of research. It would, indeed, do most undergraduates and research workers in science departments no harm to work for a month or two in a library ; for only those who have sufficient imagination can realize, without this practical experience, all the labour and organization which goes to the making of an efficient library service. One record of this kind of service is given in the reports for the years 1941-44 of the Historical Library of Yale University School of Medicine (Sterling Hall of Medicine, New Haven, Connecticut).

During the first year (1941-42) this Library, which was endowed by Harvey Cushing and dedicated on June 15, 1941, made vigorous efforts to build up its collections, especially those relating to the medical history of the War of 1914-18; the Library is also associated with the work of the National Research Council's Subcommittee on Historical Records of the medical history of the present War. The same Council financed the publication of a classified bibliography of aviation medicine prepared by the Yale Historical Medical Library, supplements to which have been requested by the National Research Council's Sub-committee. The problems which occupied this busy year are discussed in these reports. One of the Library's most useful decisions was that books should be available on loan without restriction, and many scholars outside Yale have benefited from this. Another valuable service is the opening of the Library for seven days a week.

The Library's outstanding treasures are the collection bequeathed to it by Harvey Cushing himself and the other one bequeathed by Dr. Arnold Klebs, who died in 1943 in Switzerland, where his books await transportation to Yale. These collections will place Yale in the forefront of libraries concentrating on fifteenth-century literature. To them the Library can add, among its other treasures, the collection of Prof. J. F. Fulton relating largely to the seventeenth century. Prof. Fulton's other devoted services to the management and general policy of the Library as chairman of its Advisory Board are evident throughout these reports. He is also consultant to the Army
Medical Library, the system of classification of which the Yale Library now follows. Another feature of the Library's work has been the lectures and demonstra. tions given each year by Dr. Arturo Castiglioni. The Library has issued the catalogue of Harvey Cushing's collection, which has been considered the finest gift of books by a medical man since William Hunter left his library to the University of Glasgow. Cushing's collection is rich in documents on the anatomy of the Renaissance, the surgery of Tudor England and Vesalius' books. The great historical Library now being formed at Yale is a fine memorial to Cushing, and under the care of Prof. John Fulton and his colleagues it will fare well.

G. LAPAGE.

\section{MARINE ECOLOGY IN SOUTH AFRICA*}

DROF. T. A. STEPHENSON and his assistants have studied intensively the intertidal fauna and flora of South Africa for many years, and the result is a valuable series of ecological memoirs. In Part 1 (1939) of this paper, an account was given of zonation in the intertidal belt surrounding South Africa, to which were added details of the distribution of the Patellidæ. The present part describes the distribution on the South African coasts of the more important intertidal species, and defines the geographical components of the fauna and flora. A third part is to be published later which will include, among other items, a comparison of results with those of other workers.

A very large amount of work is entailed in this survey, and the results are of great interest. Altogether a coast-line of about 1,820 miles has been surveyed and about 1,200 species identified. The most important forms on which attention has been concentrated number 318 (202 animals and 116 algæ).

The intertidal fauna and flora comprise four components - a very large warm-water component supreme in the east but dying down westward; a smaller, but important, cold-water component, paramount westward but diminishing eastwards ; a component centred about the south coast, disappearing to the eastward and westward, and a component con. sisting of species which occur around the entire coast from Durban to Port Nolloth. In addition there appear to be components of more local range centred about different parts of the coast.

Two very large elements are included; one endemic or indigenous to South Africa, the other consisting of species with an East African, Indic or Indo-Pacific range. Apart from these, other elements (Atlantic, sub-antarctic, cosmopolitan, etc.) are represented in relatively small proportions. The number of species rises steadily from west to east.

A comparison of the zonation of these coasts brings out roughly a Littorina zone, recognizable throughout although the species of Littorina change from east to west; a Balanoid zone throughout, everywhere inhabited by Patella granularis as well as by barnacles, but westward the barnacles diminish leaving the Patella dominant; a zone of Patella cochlear throughout the greater part of the coast: but at both the eastern and western ends complica. tions appear due to the diminution of that species

* The Constitution of the Intertidal Fauna and Flora of South Africa. Part 2. By T. A. Stephenson. With Plates XII-XIV and 13 text-figures. Ann. Natal Mus., 10, Part 3 (Dec. 28, 1944). 
and the consequent dominance of other forms; and the lowest zone, the sub-littoral fringe, is also demonstrable throughout though its population changes and it becomes rather vague to westward, where it represents the fringe of the (mainly sublittoral) Laminarian zone.

The replacement of certain forms is interesting. Thus the polychæte Gunnarea capensis drives out Patella cochlear in places, and mussels replace limpets in others. Also algæ replace other algæ or limpets. The illustrations of the zoning, in many cases coloured, are very attractive and informing.

Such a survey as this can only be done by steady team-work, and the difficulties overcome are very large. Prof. Stephenson is to be congratulated on the large amount of valuable work accomplished, and it is hoped that it may continue on the same lines.

\section{FORTHCOMING EVENTS}

\section{Saturday, July 7}

SOCTH-EASTERN UNION OF SCIENTIFIC SOCIETIES (at the Rothamsted Experimental Station, Harpenden), at 9.30 a.m. Fiftieth Annua Congress. Prof. W. G. Ogg: "Some Aspects of the Work at Rothamsted".

INSTITUTE OF PHYsics (LONDON AND HOME COUNTIES' BRANCH) (in the Physics Department, Imperial College of Science and Tech"The Corrosion of Metals".

Tuesday, July 10

QUEKeTT Microscoptoa CLEB (at the Royal Society, Burlington House, Piccadilly, London, W.1), at 7 p.m.-Conversation and the Exhibition of Specimens.

\section{Wednesday, July II}

Geological Society (at Burlington House, Piccadilly, London, W.1), at 2.30 p.m.-Prof. W. W. Watts, F.R.S.' First William Smith Lecture.

\section{Wednesday, July II-Thursday, July 12}

Iron AND STEeL INSTITdTe (at the Institution of Civil Engineers, Great George Street, London, S.W.1)-Annual General Meeting.

Wednesday, July II

At 10.30 a.m. and 2.30 p.m.

Thursday, July 12

At 9.45 a.m.

\section{Thursday, July 12}

ROYaI SocIety (at Burlington House, Piccadilly, London, W.1). Dr. W. T. Astbury, F.R.S.: "The Structure of Biological Fibres and the Problem of Muscle" (Croonian Lecture).

\section{Thursday, July 12-Friday, July 13}

Society of Chemical Indestry-Sixty-fourth Annual Meeting. Thursday, July 12

(At the Chemical Society, Burlington House, Piccadilly, London, W.1), at 10.30 a.m.

Friday, July 13

(At the Royal Institution, Albemarle Street, Piccadilly, London, W.1), at 10.30 a.m.-Business; at 11.30 a.m.-Presidential Address : at 3 p.m.-Presentation of the Society's Medal to the Rt. Hon. Viscount Leverhulme, and Medallist's Address.

\section{Friday, July 13}

ROYal Astronomical Society (at Burlington House, Piccadilly, London, W.1), at 4.30 p.m.-Discussion on "The Origin of the Solar System" (Speakers: Prof. W. H. McCrea, Dr. A. Hunter, Dr. R. A. Lyttleton and/or Mr. F. Hoyle).

\section{APPOINTMENTS VACANT}

APPLICATIONS are invited for the following appointments on or before the dates mentioned:

WOMAN ABSTRACTOR (Ref. F.4217.XA) with experience in scientiflc and technical abstracting; a GRADUATE PHYSICAL CHEMIST (Ref. F.4218.XA) with research experience in Rheology or Surface Chemistry; and a PHYSICAL CHEMIST (Ref. F.4219.XA) with Honours Degree and aptitude for research, by a Research Association-The Ministry $5 / 17$, Sardinia Street, Kingsway, London, W.C.2, quoting the appropriate Reference No.' (July 12).
QUALIFIED DEVELOPMENT ENGINEER to take charge of Design, Testing and Development of range of Hydraulic Pumps (location, Gloucestershire)-The Ministry of Labour and National Service, Appointments Department A.9, Room 5/17, Sardinia Street, Kingsway, London, W.C.2, quoting C.2403.XA (July 13).

LECTURER IN THE DEPARTMENT OP PHYSICS-The Secretary, The University, Edmund Street, Birmingham 3 (July 14).

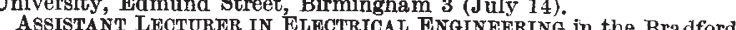
Technical College-The Director of Education, Town Hall, Bradford (July 14).

DEPUTy Borough ELECTRICAL ENGINEER-The Town Clerk, Town Hall, Great Yarmouth (July 16).

AGRICULTURAL CHEMIST, and a BrologisT-Acting Director of Agriculture, School of Agriculture, Houghall, Durham (July 18).

CIVIL ENGINEERS for service on a railway extension in Iraq-(a) Assistant Civil Engineer (Ref. E.1740.XA) capable of taking charge of setting out for railway construction, measuring up work, taking out quantities, and preparing certiflcates for payment; (b) Junior Civil Engineers (Ref. E.1705.XA) with good experience of instrument work for setting out earthworks for railway work, cross sectioning, measurements, etc.-The Ministry of Labour and National Service, Appointments Department A.9, Room 5/17, Sardinia Street, Kingsway, London, W.C.2, quoting the appropriate Reference No. (July 20). LECTURER IN INDUSTRIAI ADMINISTRATION and an ASSISTANT LECTURER IN INDUSTRIAL ADMINISTRATION-The Registrar, College of Technology, Manchester 1 (July 20).

IECTURER IN CHEMISTRY in the Constantine Technical CollegeThe Director of Education, Education Offices, Middlesbrough (July 21). RESEARCH OFFICER FOR X-RAY CRYSTALLOGRAPHY, Division of Industrial Chemistry, Council for Scientific and Industrial Research, Melbourne-The Secretary, Australian Scientiflc Research Liaison Office, Australia House, Strand, London, W.C.2 (July 23).

ASSISTANT LECTURER IN THE DEPARTMENT OF ENGINEERING-The Registrar, University College, Singleton Park, Swansea (July 30).

PROFESSOR OF GEOGRAPHY, and a LECTURER IN GEOGRAPHY, in the University of Ceylon-The Vice-Chancellor (Dr. W. Ivor Jennings) 23 Grange Road, Cambridge (July 31).

LECTURER IN FORENSIO MEDICINE AND TOXICOLOGY-The Secretary, School of Medicine Committee, Westminster Hospital Medical School 17 Horseferry Road, London, S.W.1 (July 31).

SECRETARY - The Director, School of Oriental and African Studies, University of London, London, W.C.1 (August 15)

PROFESSOR OF CHEMISTR - The Secretary, Royal Technical College, Glasgow (August 31).

LdCAS CHAIR IN THE PRINCIPLes of Enaineering Propdction (applicants should have high qualiflcations in Engineering and experience in industry)-The Secretary, The University, Birmingham 3 (September 1).

LECTURER IN SOCIAX ANTHROPOLOGY-The Secretary, The University, Edinburgh (September 30).

AsSISTANT LECTURER, or LECTURER, IN THE DEPARTMENT OF GEO. GRAPHY (with good qualiflcations in Geomorphology) - The Registrar, University College, Southampton.

HEADMASTER, Grade III (Honours Graduate, with interest in Technical Education) of the Technical High School-The Director of ducation, Education Offices, Library Street, Blackburn.

the Technical InACHER OF GENERAL ScIENCE, especially Chemistry, in and Director of Education Junior Technical School-The Secretary and Director of Education, Education Offices, Guild Street, Burtonpon-Trent (endorsed 'T').

PRINCIPAL of the Cardiff Technical College-The Director of Education, City Hall, Cardiff.

TEACHER (full-time) OF MECHaNICAI ENGINEERING SubJeCts, in the Technical Institute and Junior Technical School-The Clerk to the Education Committee, Education Offices, Trafalgar Road, Great Yarmouth.

Tracher (part-time, evening) IN PHYsiology-The Director of Education, The Polytechnic, 309 Regent Street, London, W.1.

assistant Master to teach Engineering Science, Practical GEOMETRY AND MACHINE DRAWING in the Heaton Technical SchoolThe Director of Education, City Education Office, Northumberland hoad, Newcastle-upon-Tyne 2.

ASSISTAN' Master TO TFAOH ScImNCE AND MaTHEMatics in the Oldham Municipal Technical College-The Director of Education, Education Offices, Oldham.

ASSISTANT LECTURER IN AGRICULTURAI ECONOMICS-The Registrar, University College of Wales, Aberystwyth. LECTURER IN CHEMISTRY, with qualifications in Organic Chemistry
-The Registrar, University College, Exeter.

Teacher of EngINenRIN Drawing, ENgIneEring ScIence, Practical Mathematics, Workshop Technology, Jig and Tool Drawing and Design, to Ordinary National Certificate standard in the Redditch Technical School $\rightarrow$ Mr. G. Brodrick, Education Office, Church Green West, Redditch, Worcestershire.

\section{REPORTS and other PUBLICATIONS (not included in the monthly Books Supplement)} Great Britain and Ireland

Imperial Bureau of Animal Breeding and Genetics. Technical Communication: The Semen of Animals and its Use for Artiflcial Insemination. By Dr. James Anderson. Pp. viii $+151+9$ plates. (A ber ystwyth: Imperial Agricultural Bureaux, 1945.) 78.6d. [26 Empire Cotton Growing Corporation. Annual Report of the Administrative Council for the Season 1943-1944, submitted to the
Twenty-fourth Annual General Meeting on June 5th, 1945. Pp. 18 . (London: Empire Cotton Growing Corporation, 1945.) Catalogue

A Catalogue of Books and Periodicals on Arithmetic, Astronomy, Chemistry, Electricity, Engineering, Mining, Navigation, Physics, etc
(No. 630.) Pp. 32. (London: Bernard Quaritch, Ltd., 1945.) Bd. 